\title{
Destroyal of the personal belongings of the deceased
}

On bone and flesh type of objects: Elaborating Hertz in Australia

Eric Venbrux

\section{(2) OpenEdition}

\section{Journals}

Electronic version

URL: http://journals.openedition.org/jso/812

DOI: $10.4000 /$ jso.812

ISSN: $1760-7256$

\section{Publisher}

Société des océanistes

Printed version

Date of publication: 1 June 2007

Number of pages: $97-103$

ISBN: 978-2-85430-010-9

ISSN: 0300-953x

\section{Electronic reference}

Eric Venbrux, «Destroyal of the personal belongings of the deceased », Journal de la Société des

Océanistes [Online], 124 | Année 2007-1, Online since 01 June 2010, connection on 01 May 2019. URL: http://journals.openedition.org/jso/812 ; DOI : 10.4000/jso.812 


\title{
Destroyal of the personal belongings of the deceased On bone and flesh type of objects: Elaborating Hertz in Australia
}

par

\author{
Eric VENBRUX*
}

\section{RÉSUMÉ}

Les Aborigènes Tiwi des îles Melville et Bathurst, au nord de l'Australie, sont bien connus dans la littérature ethnographique, et leurs rites mortuaires élaborés ne sont pas ce qui contribue le moins à cette réputation. Dans cet article, je me pencherai sur un aspect de la façon dont les Tiwi traitent la mort qui a reçu peu d'attention jusqu'ici, à savoir la destruction des biens personnels du défunt. Les Tiwi se débarrassent des objets d'une personne décédée pour des raisons à la fois émotionnelles et cosmologiques. Les survivants considèrent que laisser ces objets présents serait trop douloureux, mais il n'est pas nécessaire de tout détruire aussitôt : un objet choisi peut être mis de côté et utilisé pour focaliser l'émotion lors des rites mortuaires finaux, qui interviennent des mois après un décès. Les rites mortuaires tiwi ont beaucoup de similitude avec le modèle de Hertz relatif aux funérailles primaires et secondaires, bien qu'il n'existe pas de réel traitement des restes corporels. Il y a coüncidence de l'accomplissement des rituels, de la transition de l'esprit vers l'autre monde, de la période de deuil des survivants, et, dans le cas traité par Hertz, de la décomposition du corps (jusqu'au moment où les os sont secs). Dans le cas tiwi, on n'observe pas de traitement secondaire des restes, mais le traitement d'un tronc d'arbre ou de perches et l'annulation de la matérialité de la chair. La destruction des possessions personnelles du défunt, en même temps qu'une objectification de souvenirs non-matériels, servent à constituer le nouvel esprit du mort.

MoTS-CLÉS : Hertz, chair, os, destruction, biens personnels

\section{ABSTRACT}

The Tiwi Aborigines from Melville and Bathurst Islands in north Australia are well-known in the ethnographic literature, not in the least for their elaborate mortuary rituals. In this paper I will focus on an aspect of Tiwi people's dealing with death that thus far has received little attention, namely the destroyal of the personal belongings of the deceased. Tiwi people do away with a dead person's objects for both emotional and cosmological reasons. The survivors consider a continued presence of the objects too painful, but not everything needs to be destroyed at once: a selected object may be saved and employed as an emotional focus in mourning in the final mortuary rites, taking place many months after a death. Tiwi mortuary rituals have much in common with Hertz's model of primary and secondary burials, although there is no actual secondary treatment of the remains. The accomplishment of the rituals, the transition of the spirit to the other world, the period of mourning for the survivors, and in Hertz's case the decomposition of the corpse (when the bones are dry), coincide. In the Tiwi case we do not have a secondary treatment of the remains but a treatment of tree trunks or poles and the undoing of the materiality or flesh, of the deceased's former existence. The destroyal of personal belongings, along with an objectification of immaterial memories, serves to constitute the new spirit of the dead.

Keywords: Hertz, flesh, bone, destroyal, personal belongings

\footnotetext{
* Radboud University Nijmegen, The Netherlands, E.Venbrux@maw.ru.nl
} 
In the mid-1980s I did fieldwork in an ancient and remote village in the Swiss Alps. The living maintained close relationships with the dead. The latter were seen, for instance, in a procession on the mountain ridge. Some heard dead relatives in the attic and others encountered them in the fields (Venbrux, 1988, 1991, 1994). The wife of a shepherd, once told me about an eerie wake for her aunt. She was adamant there had been something wrong. The lid of the coffin stood to the wall; all of a sudden it dropped. The candles went out. And the crucifix moved.

Then followed the crux of the story: the woman had inherited nothing from her beloved aunt, not even a single object to keep as a memento! Distant relatives had taken it all away.

It went without saying that the aunt protested posthumously. The signs on the night before her burial conveyed the message that her niece - the raconteur - had been wronged (Venbrux 1988). So much for the emotional investment in clinging to the intimate possessions of the deceased. Fights over an inheritance are a matter of course in European societies ( $c f$. Lacey, 1998: 6).

Not so in an Australian Aboriginal society where I conducted fieldwork next. In contrast to the inhabitants of the Swiss mountain village, the Tiwi Aborigines from Melville and Bathurst Islands got rid of the personal belongings of the deceased. They destroyed them. Next, the dead's personal effects were buried, burnt or thrown into the sea. Whereas it hurt the European shepherd's wife not to have a memento, the Australian hunter-gatherers considered it too painful to keep such things. Upon death everything connected with the person in question became taboo.

What we have here, are two sharply contrasting attitudes to the objects that belonged to the deceased. Why is it that in certain societies or instances these things - which happen to be treasured in other ones - are destroyed?

The practice raises questions about the relationship between the living and the dead. James Frazer (1886: $75 \mathrm{n} 1)$ already speculated that

"The fear of the dead, which underlies all these burial customs, may have sprung from the idea that they were angry with the living for dispossessing them. Hence, rather than use the property of the deceased and thereby incur the anger of his ghost, men destroyed it".

The intellectualist (mentalist) hypothesis has its counterpart in a more down-to-earth, materialist one, namely that the circumstance that no one "dared inherit anything from a dead relative ensured economic equality" (Palgi and Abramo- vitch, 1984: 395). This suggests that the mortuary practice would be confined to egalitarian societies. It is not borne out by the facts, however; the potlatching Tinglit (Kan, 1989) are a case in point.

A third hypothesis in relation to the phenomenon stresses the connection between the spiritual and the material. It starts from the idea that destruction enables a transition from one form of existence to another. Albeit already mentioned by Edward Tylor, James Frazer and others, it was to become the basic tenet of Robert Hertz's theory in his seminal essay 'A contribution to the study of the collective representation of death' (1960 [1907]). Hertz writes:

\footnotetext{
"to make a material object or living being pass from this world to the next, to free or create the soul, it must be destroyed. [...] As the visible object vanishes it is reconstructed in the beyond, transformed to a greater or lesser degree. The same belief applies to the soul and the body of the deceased" (1960: 46).
}

Hertz thus accepts that people hold the belief that the destruction of material objects - including the corpse - in mortuary practice, entails a transformation to a continued existence in a spiritual sense.

The idea is central to his thesis that there exists "a natural connection between the beliefs concerning the disintegration of the body, the fate of the souls, and the state of the survivors during that same period" (Hertz, 1960: 53). Hertz formulated the theory with regard to the particular case of secondary funerals - with a strong emphasis on the ones found in Indonesia, but also dealing with examples from the Americas, Melanesia and Australia. The accomplishment of the mortuary rituals, the transition of the soul to the other world, the period of mourning for the survivors, and the decomposition of the corpse - that is, until only the dry, bare bones remain, coincide. The decay of the corpse stands central in Hertz's essay, but if we shift the focus of attention from the human material remains to the material objects that belonged to the deceased, it can be argued that in certain societies both the deceased and their intimate possessions require (partial) destruction to achieve passage to another realm of existence.

This would make sense when the personal effects are viewed as inseparable of one's material being in the world, that is, one with the imagery of the physical body. In other words, it suggests that the mortuary practice under discussion hinges on a particular concept of person. The disposal of the corpse is not enough in these circumstances, because the deceased still 
has a presence and identity of the living in the intimate possessions.

These things arouse the emotion of that person somehow still being there. Lorimer Fison and William Howitt, for example, notice with regard to the Kurnai (of South-East Australia) that:

"the personality is very limited in extent, and in reality can only include weapons, implements, and garments. But the garments, and very often the weapons and implements of the deceased were rolled up with his corpse or buried, from a reluctance on the part of his relatives to have constantly before them, after the funeral ceremonies, anything which might recall his loss and their grief." (1991[1880]: 245)

Without the disposal of the personal belongings along with the corpse the transition of the deceased from the world of the living to the world of the dead would be incomplete. We can safely assume a deterioration of the body as well as the personal apparel and artifacts.

Hertz (1960: 46) recognizes the variability in the intensity and duration of destruction: it may be a gradual, time-consuming process or occur rather instantly. Baldwin Spencer and Frank Gillen report that among the Arrente the deceased's "camp is at once burnt down, all the contents being destroyed" (1927, vol. 2: 431). Further examples from Aboriginal Australia could be cited (see Berndt and Berndt 1988: 455-465), showing either a swift or a gradual destroyal of the dead's belongings, for instance, by letting things rot or wear away. The point is that there exists a close link between the deceased and their personal possessions: and as the person has to go, so too have these things.

This notion would have made sense to the Tlingit in Alaska, because "clothing was used as another layer of the body's surface and was believed to be closely associated with it" (Kan 1989: 60). Therefore, it will come as no surprise that the personal belongings were burnt together with the corpse (ibid:: 35-36). The fire "freed the spiritual essence (inside) of the deceased's material possessions, which his spirit could now use in the other world" (ibid.: 111). Sergei Kan makes clear that for the Tlingit personal possessions, such as clothing, were an extension of the body:

\footnotetext{
"the body was covered with clothing consisting of natural substances (skins, roots, wood) transformed through human labor into a social skin which both protected and concealed the natural one. Close association existed between the person's self and his or her clothing. In this respect, the latter was analogous to various bodily effluvia and such substances as hair and fingernails, which were periodically separated from the body" (1989: 63).
}

We may, of course, also consider the physical body itself an artifact.

\section{Tiwi grieve over the loss of material objects}

The forementioned Tiwi from North Australia not only grieve over the loss of a loved one (the corpse) but also over the loss of their own personal possessions. In both instances, they use the same term. One thus closely identifies with one's effects.

Striking in this regard is the fact that personal belongings can substitute for the corpse in Tiwi graves. It is not uncommon for postfuneral rituals to be held out bush around a grave without a corpse: a grave with the personal effects of the deceased is as good as one with the (actual) body.

According to local belief, the destruction of someone's clothes equals killing that person (hence the exchange of clothes is taken as a sign of friendship and trust). The same accounts for bodily excretions and such substances as hair and fingernails, which are periodically separated from the body. And, of course, it does so for other material extensions of the body. When men burned the clothes of wives or lovers (called tupilipiami) who either had left them or were considered unfaithful, it meant they were "finished" with them.

This breaking up of a relationship also takes place in the ritual burning of clothes of the deceased (called amprakatika). Moreover, in both instances a relationship between affines is terminated in this way. (In pre-contact times, Tiwi went naked, and bereaved spouses had to be satisfied with burning pubic hair. The singed pubic hair symbolised the termination of the relationship between spouses. I was told that the "new hair" would be for the "new wife" or husband.) In the latter case, the in-laws, with the exception of the actual widow or widower, have to perform certain tasks as ritual workers ( $a m b a-$ ruwi). Among other things, they have to collect the dead person's clothes and personal belongings. These had become taboo (pukamani) after the owner's death and therefore had to be destroyed, buried, or thrown into the sea. The tasks of the ritual workers could not be carried out by the dead person's relatives in other categories of bereaved kin, who were restricted by mourning taboos. They are the only ones allowed to handle and dispose of the corpse. And they have to destroy or dispose of the newly dead's personal effects as well. 
These objects become taboo upon death, because they are closely associated - either as "extensions" or as "stand-ins" - with the lifeless physical body - an object itself. Without the disposal of the personal belongings along with the corpse the transition of the deceased from the world of the living to the world of the dead would be incomplete. The ritual workers destroy, or get rid of, the things of the dead in various ways. The personal effects are broken to pieces, buried, left on the grave, burnt or thrown into the sea. The workers clear out the house of the deceased, "empty the cupboards" and all. The personal belongings, together with a heavy stone, are sometimes wrapped in plastic, tied with a cord. Next, this is taken in a dinghy and thrown overboard to the bottom of the sea. Things of the dead are left behind on the grave to decompose. Or they are buried with the corpse.

Nobody wants these things because it hurts the survivors to be reminded too much of the deceased (see for the ambiguity of such destructions and related feelings also Lemonnier, this volume). Besides, anything associated with the identity of a living person becomes taboo after death: the personal names, voices on tape, images in photos, house and yard, places frequented, the place of death and even the land out bush may not to be visited or hunted. This lasts for a considerable time: the postfuneral rites must have been accomplished and cleansing rites with smoke must have been performed. Whether it takes months or years, very much depends on the emotions and needs of the survivors. Houses of the newly dead may be abandoned forever. The belongings of the deceased, more than anything else, make people sad. The erasure of these things is necessary.

So a guitar may be broken into pieces, a car wrecked, a house destroyed, and almost new clothes burnt or dropped on the bottom of the sea. Symbolic killing is also an important theme in the ritual drama, given its purpose to direct the spirit of the dead from the world of the living to the world of the dead. This killing or destruction is so sudden and abrupt as well as irreversible that it serves perfectly as a powerful image of the radical breaking of ties and separation in mortuary ritual. According to Hertz, "It is so true that natural death is not sufficient to sever the ties binding the deceased to this world, that in order to become a legitimate and authentic inhabitant of the land of the dead he must first be killed" (1960: 73; see for another good example, Taylor 1996). Also the deceased's personal belongings, as we have seen, are subjected to some kind of killing or destruction by means of burning, drowning or burial. It is part of the process of killing the dead person, which is deemed necessary by Hertz.

When not directly put away after death, things like clothes, mattresses and sheets may later sometimes be deliberately used as a focus in ritual when an emotionally compelling remembrance of the dead person is desirable. The house formerly occupied by the deceased and items hard to replace (such as cars, dinghies, VCRs, football trophies) would, however, be ritually cleansed with smoke. After cleansing had taken place, people might move into the house again or it might not be reoccupied for a considerable time, if ever. It would all very much depend on the emotions and needs of the people concerned.

Before the cleansing ritual, houses and yards would be taboo (only accessible to the ritual workers who gather the personal belongings of the deceased) and often marked as such. In case of a fatal motor vehicle accident, the spot where the accident had occurred would become taboo and the road would be blocked off. A special "open "em up" ceremony (ampuraprapununga) or cleansing rite with the erection of a mortuary pole would have to be performed before the road could be used again by traffic. Sometimes after the death of a senior person the road or pathway to that person's "country", an area with an ancestral grave, would be temporarily closed. After the death of the most senior (important) person of a country, a relatively rare occurrence, the country may be ritually cleansed.

Whether places other than the house occupied by the deceased and the place of death would have to be ritually cleansed varied depending on the social position of the deceased, the type of death, and, of course, people's sentiments and needs. The need to ritually cleanse a number of places would be especially important after unexpected and sudden deaths, the most shocking of all. It was after these unforeseen deaths, I was frequently told, that the spirits of the newly dead bothered the living. The places frequented by these persons when alive would then be cleansed. Hereafter these things will be destroyed also.

Jack Goody (1962: 307) explains the widespread practice of the destroyal of the belongings of the dead as follows:

"From the actor's point of view, goods are destroyed not only because they are dangerous to the survivors, but also because of the related idea that the holders of rights continue to maintain these interests even in death". 
Again, such goods seem to be seen as inseparable from the rightful owners. The rightful owners here are the deceased. The practices of widow-burning and the killing of slaves - at the death of their owner - might also be seen in this light.

Peter Metcalf and Richard Huntington (1991: $25)$ rightly note that "the issue of death throws into relief the most important cultural values by which people live their lives and evaluate their experiences. Life becomes transparent against the background of death, and fundamental social and cultural issues are revealed."

\section{Embodiment: production of material objects for the deceased's spirits}

Besides intimate possessions being destroyed there are in Tiwi mortuary ritual also things for the dead. The ritual workers produce large, elaborately carved and painted polychrome poles. These sculptured tree trunks are erected around the grave at the conclusion of the cycle of mortuary rituals. Art historian Jennifer Hoff (2000) has described them as "gifts for the dead." These things for the dead, however, are also things of the dead. The workers, who are the only ones who may dispose of the corpse, cut trees in the area that is perceived as the deceased's "country" or land. This occurs after the burial of the corpse, when the area is taboo for everyone except the workers.

In Tiwi mortuary ritual we do not have a secondary treatment of the remains but a treatment of tree trunks or poles (see also Venbrux 1995). They are cut in the area surrounding the grave, preferably from the bloodwood tree (wuringelaka). A red substance resembling blood flows from the stem when this type of tree is cut. When head-cutting was still a general practice (at least until the mid-1950s) human blood likewise had to flow on the grave. Next, the wooden stems are "skinned," the bark is removed. Then they are carved with an axe in abstract but unique shapes (with forks or limbs; and also openings in the poles). The white poles of hardwood, about as tall as a human being, are dried over a smoking fire. When dry, they will be painted with ochres supplied by close relatives of the deceased.

The making of the poles parallels the ritual processing of the bodies of the bereaved. The bodies of close relatives of the deceased also go through a fire, made by the workers, and are ritually cleansed with smoke. Both are laid down to be painted with ochres. The geometrical de- signs on the mortuary poles are the same as those applied to the bodies of the bereaved.

Lying down has the connotation of death or sleep in contrast to standing up. The people with their bodies painted up - raise to their feet; likewise a mortuary pole will be erected, and be called "the one that is standing up" (apurununinginti). Although movements are made with the poles, they cannot display the energetic dances of the living. Tiwi, however, believe that the spirits of the dead simultaneously do so. Furthermore, the Melville Island bloodwood is a species demonstrating exceptional vitality: the tree "may shoot up to 2 or 3 metres in a few months" (Hearne, 1975: 61). The mortuary poles symbolize the vitality, or life essence, of the durable bloodwood trees. The wailing participants hold the poles, which first have been hit or "killed" by the workers, as if these represent a tactile presence of the deceased.

The durable wooden poles might be seen as relics. The poles as well as graves - no matter they contain corpses or things of the dead provide the patrilineal descendants of the deceased with the strongest possible claims to the land in the area concerned. Therefore, there can be strong disagreements about where a new grave has to be located. During my fieldwork, for instance, a corpse was kept in prison overnight to prevent some relatives from stealing the body to have it buried elsewhere. The burial sites with mortuary poles are the places where the spirits of the dead "live". Often spirits are connected with particular trees. I was told the poles were erected at the time of the secondary rituals to keep the spirits there. The lapse of time between the funeral and post-funeral or secondary rituals was not related to the decomposition of the corpse to the point "when the bones are dry", but to "skinned" (or defleshed) dry wood. The durable poles, embodying the spirits of the dead, mediate between the living and the death. For example, they do so in the promotion of good hunting, luck, protection, and health of the living. To the last purpose some used to bring cans of beer, put it on a pole. The poles or relics mark and give permanence to the transmission of shared rights to land across the generations. This in contrast to the things of the dead, which are destroyed by people of the same generation.

Personal belongings substitute for the deceased, when there is more than one grave as each classificatory father can organize funeral rites - with or without a corpse - and personal effects are buried instead of the corpse. Tiwi people do away with a dead person's objects for both emotional and cosmological reasons. 
Fred Myers reports that the Pintupi of Central Australia "regard themselves as having an assured identity no matter what happens to the personal possessions" (1991: 73). They are given away to distant relatives or destroyed - even a nearly-new motor-car could be burnt. The sight of these things causes grief. Myers (1991) points out that these things are deemed replaceable, in contrast to the ancestral connections to the land, which can be seen as an objectification of social relationships. For the Pintubi the real value thus lies in social investments, not in material things accumulated throughout a lifetime. People, as he puts it, are "burning the truck and holding the country". They identify with places, and these connections are shared and irreplaceable. Destroyal of the deceased's personal belongings is performed by people of the same generation, while the immaterial memories of connections to the land have permanence and are transmitted across generations.

Destroying belongings of the dead is a widespread practice. Roger Lohmann (this issue) unravels the various strategies employed by the Asabano in Papua New Guinea. He writes from his own experience: "It amazed me when they would cut down fruit-bearing trees that a deceased loved one had planted and tended for the benefit of her family" (pers. comm.; see also Hertz, 1960: 38). According to Goody (1962), destruction of the intimate possessions of the deceased took place in Native North America, Aboriginal Australia and pre-Christian Europe. Both Arnold van Gennep (1960 [1909]: 164) and Ronald Grimes (2000: 220) regard the destroyal of the deceased's possessions as a rite of separation. Van Gennep (1960) nevertheless maintains that "death is an initiation". We have seen that it is as much a rite of incorporation, for the destruction accomplishes the transition to the world of the dead. It accompanies the decomposition of the corpse; when the bones are dry, according to Hertz, the deceased has passed to the other world. The personal effects are very closely associated with the physical body and personality of the deceased and, therefore, it is necessary that when the corpse decays that the additional "flesh" or the dead's belongings disappear as well.

\section{Conclusion}

Whereas transference of property of the deceased to survivors has been abundantly dealt with in the anthropological literature (e.g., Goody, 1962), the phenomenon of the erasure of the dead's personal belongings is still in need of explanation. In this article I have been concerned with the question of why people would want to destroy or get rid of the intimate possessions of the deceased.

My point of departure was Robert Hertz's seminal essay 'A contribution to the study of the collective representation of death' - first published in French in 1907, and in an English translation in 1960. The impact that Hertz's ideas continue to have on anthropological theorizing of mortuary ritual can hardly be underestimated.

Here I have extended his argument - taking the body as root metaphor - to the treatment of material objects related to the deceased. These objects might as well be part of the concept of the person.

The body, including its material extensions, is of crucial importance in the relationship between persons and things. I looked at embodied material dimensions of Tiwi death rituals, asking why some objects are kept as relics or heirlooms, while others are destroyed.

In his review of mortuary practices worldwide, Nigel Barley (1995: 85) asserts that "two lines of thought are common where intimate possessions are concerned": they are destroyed or kept as mementos. It is my contention that in both cases they are given special treatment. In both cases, it helps to construct a new relationship between the living and the dead.

Hertz argued that the soul or spirit of the deceased has passed to the other world when the corpse's flesh has gone, and the bones are dry. The personal effects are very closely associated with the physical body and personality of the deceased and, therefore, it is necessary that when the corpse decays that the additional "flesh" or the dead's belongings disappear as well. They are destroyed to constitute the new spirit of the dead.

Where the deceased's belongings are not destroyed but kept as mementos as in the case of the poles, they might be seen in analogy to Hertz' model as a different class of objects: not of the "flesh"-type but of the "bone"-type - these things become relics or heirlooms. They serve as mediators, a means of communication, between the living and the dead.

In both cases though - the objects being kept or destroyed - they are given special treatment. The practices are telling about the connection between the material and the spiritual.

Changes in the treatment of the corpse and associated material objects one therefore would 
expect to have consequences for people's perspective on death. Alternatively, it suggests that changes in ideas about death might reflect in the adaptation of ritual practices. In other words, when people's notions of the spiritual change the material side of mortuary ritual will change as well, and vice versa.

\section{Acknowledgement}

I am very grateful to Pierre Lemonnier for his invaluable suggestions and comments on this paper. Moreover, I want to acknowledge his great help in putting together this issue and making its publication possible.

\section{BIBLIOGRAPHY}

BARLEY Nigel, 1995. Dancing on the Grave: Encounters with Death, London, John Murray.

BERndT Ronald M. and Catherine H. BERndt, 1988. The World of the First Australians, Canberra, Aboriginal Studies Press.

FISON Lorimer and A.W. HowITT, 1991 [1880]. Kamilaroi and Kurnai, Canberra, Aboriginal Studies Press.

Frazer James G., 1886. On certain burial customs as illustrative of the primitive theory of the soul, The Journal of the Anthropological Institute of Great Britain and Ireland 15, pp. 63-104.

Goody Jack, 1962. Death, Property and the Ancestors, London, Tavistock.

Grimes Ronald L., 2000. Deeply into the Bone. Re-inventing Rites of Passage, Berkeley, University of California Press.

Hearne D.A., 1975. Trees for Darwin and Northern Australia, Canberra, Australian Government Publishing Service.

Hertz Robert, 1960[1907]. A contribution to the study of the collective representation of death, in Death and the Right Hand (trans. Rodney and Claudia Needham, Glencoe, Ill., Free Press, pp. 2586, pp. $117-171$.
HoFf Jennifer, 2000. Tiwi graveposts, in Sylvia Kleinert and Margo Neale (eds), The Oxford Companion to Aboriginal Art and Culture, Oxford, Oxford University Press, pp. 174-179.

KAN Sergei, 1989. Symbolic Immortality: The Tlingit Potlatch of the Nineteenth Century, Washington, D.C., Smithsonian Institution Press.

LACEY Robert, 1998. Sotheby's: Bidding for Class, London, Little, Brown and Company.

Metcalf Peter and Richard Huntington, 1991. Celebrations of Death: The Anthropology of Mortuary Ritual, Second Edition. Cambridge, Cambridge University Press.

MYers Fred R., 1991. Burning the truck and holding the country: property, time and the negotiation of identity among the Pintupi Aborigines, in Tim Ingold, David Riches and James Woodburn (eds), Hunters and Gatherers, vol. 2: Property, Power and Ideology, Oxford, Berg, pp. 52-74.

Palgi Phyllis and Henry ABramovitch, 1984. Death: A Cross-Cultural Perspective, Annual Review of Anthropology 13, pp. 385-417.

Spencer Baldwin and F.J. Gillen, 1927. The Arunta. A Study of a Stone Age People, 2 vols, London, Macmillan.

TAYLOR Anne Christine, 1996. The soul's body and its states: An Amazonian perspective on the nature of being human, Journal of the Royal Anthropological Institute 2, 2, pp. 201-215.

Van Gennep Arnold, 1960[1909]. Rites of Passage, Chicago, University of Chicago Press.

VenBRux Eric, 1988. Een bruid in het graf. Een antropologisch onderzoek naar collectieve geloofsvoorstellingen rondom de dood in een Zwitsers bergdorp, Nijmegen, Sociaal Antropologische Cahiers 21, Instituut voor Culturele en Sociale Antropologie.

-, 1991. A death-marriage in a Swiss mountain village, Ethnologia Europaea 21, pp. 193-205.

- 1994. Het meisje en de dood, in Henk Driessen and Huub de Jonge (eds), In de ban van betekenis. Proeven van een symbolische antropologie, Nijmegen, SUN, pp. 217-246.

-, 1995. A Death in the Tiwi Islands. Conflict, Ritual and Social Life in an Australian Aboriginal Community, Cambridge, Cambridge University Press. 
